\title{
Revealing Expression through Taboo Words in the Novel Peepshow
}

\author{
Arief Nugraha \\ Balikpapan University \\ gaularif84@gmail.com \\ Waladdin Panggabean \\ Balikpapan University \\ waladdin@uniba-bpn.ac.id \\ Adi Prautomo \\ Balikpapan University \\ adi.prautomo@uniba-bpn.ac.id
}

\begin{abstract}
:
This journal focused to the revealing expression from the taboo words in the novel Peepshow. There are two objectives of this research, they are; to find out the forms of taboo words in the novel Peepshow, and to explain how the expression through taboo words revealed in the novel Peepshow. The theory used in this research is the sociolinguistics analysis using Batistella's theory of taboo words and expression theory according to Ekman's theory of the expression.The methodology employed is descriptive qualitative research in which the researcher tried to present the issues descriptively. As for the data, they were collected from the excerpt of novel's quotation. The novel's quotations were taken out as the primary data. From the result of the research, the researcher finds that the forms of taboo words in the novel Peepshow is Obscenity into the use of impolite words in body excretion and the use of impolite words in sexual function, Vulgarity divided into the use of impolite word in body anatomy and the use of impolite word in sexual function, Profanity in the use of impolite words in religious cursing, and Epithet in the use of impolite words by people's status. Meanwhile the researcher founds the revealing expression through the taboo words consisted of sad, angry, fear, happy, surprise, and disgust through obscenity, vulgarity, profanity and epithet.
\end{abstract}

Keywords: revealing expression, taboo word, Peepshow 


\section{INTRODUCTION}

Language is the one of tools used by people to talk with another person or in one society group to communicate properly. Language can also be found in many kinds of literary works. Novel is one of the literary works contains dialogue and written by the author based on their experience through ideas, imagination related to their life to the story. Some novels also use informal language or words that cannot be used in society, and because the language is considered taboo. The researcher's reason use the novel Peepshow is because it contains the kinds of taboo words which helps the researcher to analyze the data in the research.

According to Batistella, taboo word is a kind of language about any word that contains bad meaning to the listener used on certain communities of society. Most of the taboo words used by people who have low education or people who live in social discrepancy and this becomes a habit of people in low social and education to use these words frequently to show their status $(2005, \mathrm{p}, 72)$. Taboo words is an utterance that most of the people cannot use because contains the violation of politeness norm.

The use of taboo words could affect someone's expression showed by people. Expression is important when someone utters taboo words. This statement is added by Ekman (1984) that "expression is a terms to experience of emotion by people who deliberately put on their feelings to convinced the other" (P, 321-322) In using expression, the way of people to reveal their expression to someone can be different depends on their emotion whether they were happy, sad, or angry. Ekman (1986) tells there are six forms of expression based on the emotion which is happy, sad, angry, disgust, fear, and surprise (p, 159-160). By using the kind of expression above, the taboo words could deliver the expression that they had to another people to show happiness, feel angry, or fear.

\section{LITERATURE REVIEW}

Taboo word is a word used by a person or person that has a bad meaning to the user. According to Batistella (2005), "Taboo itself is something that is forbidden or prohibited to do or expressed especially in a social environment. Taboo words are used to refer to race, ethnicity, appearance, religious terms, and excretory or body function in a harsh way" (p, 72). From the previous statement, the researcher explains taboo words used by people to judge someone in a bad manner from his/her status or uses to insult someone refers to the religion, body and sexual function, and race, social status from the taboo words.

\section{Forms of Taboo Words}

Taboo words are related to sociolinguistic because taboo words is a phenomenon of the bad language used in the social life. Batistella $(2005$, p.72) argued that there are four types of in taboo words, which are obscenity, vulgarity, profanity, and epithet. 


\section{Obscenity}

Obscenity means that someone wants to attract the other people's attention in a bad manner and usually added by taboo words that refer to body excretion and sexual action.

\section{Profanity}

Profanity is similar to curse word, but it more has a religious connection to God. Profanity are used when someone is frustrated or fell someone is making him/her angry. Profanity used terms of religion to the people who followed the God's rule and avoid what is prohibited by God. The use of profanity often used by people that do not obey God's rules and considered break the religion's rules.

\section{Vulgarity}

Vulgarity is the expression to be vulgar or impolite because of the harsh language used by uneducated people. The language used is to show the hate expression or interest for someone. These types of taboo words consisted of the terms body anatomy and sexual function.

\section{Epithet}

Epithet is taboo words that use anyone's identity to be mock by his/her personality, race, religion, appearance, etc. Epithet is used when someone is shown the hatred of someone with a rude manner.

\section{Revealing Expression through Taboo Words}

Expression is one of human natural responses to anything. Expressions have their own kind from the feeling used and explained by Ekman (1986, p.159-160) where he argued that "emotion can be classified from the affective phenomena by the signal of their characteristic consisted in six forms of expression which is happy, sad, angry, disgust, fear, and surprise". In this research, the researcher focused on the research to find forms of expression categorized in six expression which explained based on Ekman's theory from the quotation below.

\section{Sad}

Sad is an expression to convey feelings of grief, depression, disappointment, misery, or despair. Sad is also caused by people's response whenever they lost someone they were loved. Sad also describes the range of emotional states that had been experienced by people from mild disappointment into extreme despair.

\section{Angry}

Angry is an expression on people how expressing their anger to a person or an object. People expressed the angry expression in a different way for example: use a physical violence, a word to insult someone, and in verbal abuse. 


\section{Fear}

Expression of fear involves the feeling of someone were under threat and shocked whenever they see frightening event and associated on how people could keep their distance away from the source of threat. Fear expression triggered by something that can terrified anyone like, fear of certain animal, fear of darkness, fear of rejection in social interaction.

\section{Happy}

Happy is the most desirable form of expression in which happy describes the feeling of pleasure and peace condition. Happy expression is triggered by experiencing something beautiful or something humorous, for example, when people love you and you happily accept their love, or personal achievment.

\section{Surprise}

Surprise is the expression that come when people suddenly react with the loud sound or any movement unexpectedly or suddenly. The function of surprise is to focus on something that coming whether it is dangerous or not.

\section{Disgust}

Disgust is the expression arises from the feeling of something unpleasant to someone or something that considered offensive. Expression of disgust contains a range of intensities from the mild dislike and to intense loathing which all forms of disgust triggered by feeling to something repulsive and toxic.

From all the forms of taboo words and the expression revealed, the researcher find the correlation of the expression and taboo words. People utters taboo words as to expressed their emotive feeling or as a response from people's insult that makes someone shows some expression accompanied by taboo words .

\section{RESEARCH METHODOLOGY}

This research uses qualitative research method. Descriptive qualitative method used by collecting data in form of quotation,words and text by using the novel's dialogue and a script from the novel itself to give guidance when the data is analyzed. The research is aimed to analyzed the forms of taboo words and find how the kinds of expression revealed through taboo words to get the revealing of expression by the use of taboo words. Data sources are divided into primary and secondary. The source of primary data in this research is the novel Peepshow. The researcher choose this because it contains a lot of impolite words which help the researcher to classified them in forms of taboo words and the expression revealed through taboo words. Secondary data is obtained from journal, book, and some thesis that related to this research as the primary data supporter.

Procedures of collecting the data are as follows: first, reading about the theory discussed taboo words and kinds of expression used in this research, second, read the novel as the 
object of research repeatedly until the researcher knows about the taboo words and the expression revealed which is classified, discussed and underlined the excerpt that has taboo words and the third, gives the explanation about forms of taboo words that portrayed in the quotation based on the theory to answer and explained the data that collected in the form of excerpt.

\section{FINDINGS AND DISCUSSION}

\section{The Forms of Taboo Words and The Revealing Expression Through Taboo Words}

\section{Obscenity}

Obscenity where explained about word related to body excretion and sexual action used to degrade people's feeling and to mock people from the terms of human defecation which some people uttered it to attract people's attention whereas there are three expression revealed in this excerpt is angry, fear, and disgust.

Thanks for sicking Farquhar onto me, you're lying scumbag piece of shit. Was it you or him who broke into my flat? Kelvin was beside himself with worry and apologized profusely when I called to let him know I was all right. (Redhead, p.166)

The statement above shows Simone was awaken from her sleep and realize that her item was stolen. Then, she was angry and called Alex to accused him for working with Farquhar and Simone utters word "shit" which refer to body excretion and categorized as obscenity. Obscenity is used frequently in this citation which contain terms of sexual and body excretion in the rough manner and must not used in the daily conversation because it could hurt people feeling and make people offended and also used to attract people's attention on the use taboo words.

Angry expression were used in the excerpt above was accompanied by a word to insult someone. It is included in angry expression because of the unpleasant action and make someone utters a bad words. Emphasizing the angry expression is shown by using swear word is done by a lot of people. Another examples of obscenity in different expression is shown below.

I searched under the coffee table and around the stereo but couldn't see anything. What if he had someone outside with directional microphone? We'd learned about those in class. Oh shit. I walked around in circles. Oh shit, oh shit, oh shit. If I called the police and Chloe ended up with a bullet in her head I'd never forgive myself. (Redhead, p.24)

The statement above shows Simone were talking to herself because her friends were kidnapped and needed to find a way to help her friend. Simone goes confused and is afraid of her friend's safety. It makes her utter "shit" which refers to body excretion terms and categorized as obscenity. The use of obscenity itself has widely used by people in society 
even in their daily activity at different situation which considered impolite if used in another country because it breaks the politeness constraint.

The word above categorized as fear expression because involves the afraid feeling on some threat and shocked whenever they see frightening event and associated on how people could keep their distance away from the source of threat as people will say some taboo words to relieve their fear on something.

I hate you, I gasped, I fucking hate you. I did. I hated the hold he had on me. It spurred him on and he fucked me harder, deeper, like a man possessed. My head banging against the wall and the wall shook. It was so intense I thought I'd pass out. (Redhead, p.185)

The quotation above shows Simone and Mick arguing in the front of Simone's apartment. Mick provokes Simone to solve the murder mystery by herself and makes Simone feels suspicious as Mick told Simone that he cheats and has been sleeping with another woman. It makes Simone brokenhearted and Simone utters the word "fucking" which categorized as obscenity and an expression of disgust.

The obscenity is used commonly in conversation between people in the excerpt above which contain the terms of human sexual action and excretion that could hurt people's feeling and delivered their true emotion to someone. The expression used as the emotion is disgust where the expression arises from the feeling of something unpleasant to someone or something that considered offensive and its contains a range of intensities from the mild dislike and to intense loathing which all forms of disgust triggered by feeling to something repulsive and toxic. From the explanation above, disgust feeling shown in the excerpt because people feel uncomfortable to someone which makes them uttered taboo words to intensify their feeling.

2. Vulgarity

Vulgarity is the expression to be vulgar or impolite because of the harsh language used by uneducated people. The language used is to show the hate expression or interest for someone. These types of taboo words consisted of the terms body anatomy and sexual function used in the rough manner. The expression revealed in this excerpt which is happy, angry, and disgust.

"Hi, Vivien", She said. "I'm Aurora."

"I love your boots."

"Thanks, Kitty's Fetish Wear, four hundred bucks."

I finished zipping them and straightened up, shaking her hand. "I love your tits." It just slipped out.

"Doctor Eng Pen Tan. Twelve thousand." Aurora laughed. (Redhead, p.37)

The excerpt above shows Simone was come to her workplace which it is her first day on the job. She meets and greets some of the strippers and they introduce themselves and one stripper come to meet him named Aurora and she loves Simone's body postures and praise her and makes Simone happy about it. 
The use of taboo words above reveals the happy expression as Aurora uttered "tits" that refer to vulgarity. The words above has a meaning of breast which used as the bad words in the formal conversation and also showed Aurora's happy expression. Happy expression on the excerpt above used when someone has the pleasant experience from something good, beautiful or something humorous which Aurora loves Simone's breast to show her happiness toward something by used some bad words that used in the informal condition.

"Look," I said, trying to reason with him.

"What's this all about?" Sweat beaded on his forehead and the open pores of

his nose. His breathing was rattly and deep. "What's all this about?" He

bellowed. "What's all this about, you stupid cunt?" (Redhead, p.163)

The statement above shows Simone is arrested as the accusation of prostitution and then, Simone argues with the head of Victorian police named Dick Farquhar and try to reason with him which make Farquhar angry and utters word "cunt" that refer to vulgarity and categorized as the angry expression.

The word has the meaning of "vagina" which considered impolite if used on the public conversation which vulgarity used to show the bad words in form of human anatomy and sexual function. The researcher explains of the conversation above used the angry expression which anger followed by a bad words used to insult someone and triggered by the feeling of anger and use to offend people's pride and feeling in an impolite manner.

Why would he keep the knife in his house? Why would he keep it at all? Maybe he wanted to plant it on someone. Who knows? He's arrogant prick, refuses to answer any question, says none to the stuff we found belongs to him and that we planted the knife. (Redhead, p.211)

From the quotation above, it shows Simone and Tony talk about the biography and history of the head of police named Dick Farquhar which Simone thought has a connection with the murder. Tony answers that Farquhar is an arrogant cop who seldom talks to others.

The use of taboo words above revealed the disgust expression by Tony as he uttered "prick" refers to vulgarity. The word on the quotation above contains the meaning of "penis" and considered impolite in the formal situation which used to insult people and degrade their pride and if used directly to the people referred, it cause the people showed their disgust expression which is triggered by feeling of toxic caused by something unpleasant and considered offensive which lead someone expressed their disgust expression followed with bad words utterance as to insult someone from their behaviour.

\section{Profanity}

Profanity is similar to curse word, but it more has a religious connection to God. Profanity are used when someone is frustrated or fell someone is making him/her angry. Profanity used terms of religion to the people who followed the God's rule and avoid what is prohibited by God. The use of profanity often used by people that do not obey God's rules and considered break the religion's rule. Profanity also accompanied by expression of fear, angry, and surprise which explained below. 
Christ, who was I kidding? I felt humiliated and ashamed.And scared shitless. Tears pricked my eyes and I blinked rapidly to get rid of them. After what seemed like an hour I lay my head down on the table in front of me. My wrist, arms and shoulder sparked with pain and the panic had been replace with exhaustion. (Redhead, p.160)

The quotation above shows Simone is arrested by the police because the accusation of prostitution. Simone then feels scared as she starts dropping tears. The revealing of fear expression in which she uttered "Christ" that refer to profanity. The word above considered sacred because it refer to the name of God in Christianity which cannot be used as a curse word to insult someone because it could offend people who followed the religion and considered impolite which is should used in the religious activity.

In some circumstances, The word above uttered by people whenever they afraid of something which describe fear is the feeling when someone is under threat because of something. It can make them struggle to avoid the source of threat and cause them to utter the inappropriate word above as the result of fear expression.

Where the hell was the cavalry? I'd done my bit. I heard shoes drop to the floor and Bob and Jason laughing and talking. I had a pee and washing my hands thoroughly and slowly, brushed my hair, powdered my nose and put on more lipstick. Damn you, Alex. (Redhead, p.197)

The excerpt above shows Simone was have a business with two guys in the Farquhar's room which Simone asked Alex for his troops come to the room and caught Dick Farquhar. The response is not answered and Simone is disappointed and curse Alex which shows Simone is angry to Alex.

The angry expression which Simone utters "damn" refers to profanity. It is used as a purpose to curse someone which cannot be used in the outside of religious activity which people use the word above followed by angry expression. Angry expression is triggered when someone shows their dissatisfaction and sometimes they combined the angry expression by some taboo words to emphasize the curse word especially in profanity where people expressed their dissatisfaction in a forms of angry to insult someone by using the religious terms to emphasize their emotion.

I came out suddenly. Jesus, how long had I been out? I tried to think. I needed to think. I needed a weapon. A stick, anything. I felt around the base of the tree and my hand came to rest on small sign staked into the earth. (Redhead, p.222)

The excerpt above shows Simone when she is awakened in an unfamiliar place which she was surprised and confused if someone has kidnapped her. She tries to think clearly and decides that she needs to find a weapon to defend herself. She is collapsed all of the sudden. The revealing of surprise expression as the use of taboo word and Simone utters "Jesus" categorized as profanity. The word considered as a sacred name of God and cannot be used in any circumstances outside the religious activity because it could offend people's religion and cause harm to people. 


\section{Epithet}

Epithet were used by people as the insult because it has the utterance that considered impolite and rude because it refers to people's ethnicity, gender, job, and status where in the real life most of people cannot accept it and considered it as an insult and could provoke someone to show their anger to people who mocked them. The epithet are used frequently with some expression which makes the swear word is unique to used in some circumstances whereas it explained by expression of disgust, angry, and surprise.

Her mouth was opening and closing, like a guppy, no sound coming out.And when I got to her, I reached out, hugged her, looked her in the eye and said, "I forgive you". Mick Laughed. No way. I Would have smacked the silly bitch. What happened then?. (Redhead, p.138)

The statement above shows Simone and Mick talk about their experience working on the mini market. Mick listens to Simone's story and is shocked when he hears it which make Mick feel disgusted and told Simone that he would slap the customer if Mick as a Simone. The revealing of disgust expression as the use of taboo words where Mick uttered "bitch" and refers to epithet. The word above has a negative meaning of woman who worked by selling the sex services for money and considered impolite in the formal conversation.

I raised my eyebrows. Chloe groaned. Chloe: I know not the smartest things to say to a prick like that. So he goes, You don't know who you're dealing with bitch. You want to wind up dead? And I say. Simone: You don't fucking scare me, you better watch your mouth, motherfucker cause I know people (Redhead, p.7).

The statement above shows Simone and Chloe talk about their job and both of them hate their boss because their boss treated them like a prostitute. At one point, Simone tells Chloe that she would like to report her boss to the police. Chloe does not agree with Simone's statement and Chloe tries to frighten Simone using bad words. Simone is angry towards Chloe's attitude as a stripper. The revealing of angry expression as the use of taboo words which Simone utters "motherfucker" that refers to epithet.

The word on the excerpt above has a literal meaning of a man that doing sexual activity with her mother or aunt and considered impolite to use in the formal conversation because it could trigger someone to show their angry expression by provoke someone with bad words. Moreover, bad words sometimes followed by the angry expression which people utters taboo words to insult people from their status.

Chloe: Simone! Her blond hair was in rollers and she popped out of a small pink bikini top. Simone: you're keen. I glanced at the clock. It was three fortyfive in the afternoon, I've still got fifteen minutes. Chloe: He's dead. She was clutching the pm edition of the herald sun. That fat bastard is been murdered. What fat bastard? (Redhead, p.5)

The excerpt above shows that Simone and Chloe enjoy the scenery inside their apartment and read the newspaper. Suddenly, she screams when she read in the newspaper that her 
boss, Frank was killed in an incident. Chloe uttered "bastard" categorized as epithet to provoke Simone's attention by Chloe insult her status and Simone replied and calling her "bastard".

Provocation in this excerpt is succeeded because there is a feedback between both of the people. The revealing of surprise expression through taboo words where Chloe utters "bastard" that refers as epithet. The word above refers to someone who was born without a legal parent and considered rude if it uses to someone especially for the people who uses fluently bad words because it can cause someone feels offended and the expression of surprise when they had some bad news where it is triggered by an unexpected movement or something that just have been occur and cause them to express it through taboo words to emphasize the surprised feeling at something that came suddenly at people.

\section{CONCLUSION}

The researcher concludes that taboo words are the most form of language that cannot be used directly in the public place or in the society because it cannot be accepted by most of people and could offend people's pride and feeling from their status, religion and, sexuality. Taboo words is not always considered impolite in most of conversation because some people in certain part of the society always use it in the daily conversation in the same group of one society which considered as a solidarity, intimacy, and friendship and can be used only by people of the society itself and some people can also used the taboo words accompanied by some expression which emphasize people's intention whenever they uttered taboo words such as expressed their happiness, sadness or anger which most of people cannot use the kinds of expression along with the taboo words because it can invited enmity, and embarrassment from other people which if it used, it can lead someone to embarrassed themselves, their reputation and humiliating their family for the use of taboo words itself. The words is can also be used as the benchmark on how people in one country is well-civilized and cultured.

\section{References}

Abrams, M, H (1999). A Glossary of Literary terms, seventh edition. USA: Earl Mc Peek. Anggita, N, F (2015), A Sociolinguistic Analysis of Taboo Words in Bad Teacher Movie. Yogyakarta: Universitas Negeri Yogyakarta.

Allan, K. \& Burridge, K. (2006). Forbidden Words Taboo and Censoring of Language. New York: Cambridge University Press.

Bogdan, R. C. \& Biklen, S. K. (1982) via Simon (2011). Qualitative Research for Education: An Introduction to Theory and Methods. Boston: Allyn\&Bacon, Inc.

Afrizal (2016). Metode Penelitian Kualitatif. Depok: PT. Raja Grafindo Persada.

Batistella, 1. E. (2005). Bad language are some words are better than others. New York: Oxford University Press. 
Prologue: Journal on Language and Literature Vol.6 No.2 (2020)

Cresswell, W. J. (2009). Research Design, Qualitative, Quantitative, and mixed method Approach. California: Sage Publication

Denzin, N. Via Phil And Susan Turner, (1978), Socioligical Methods. New York: Mc Graw Hill.

Ekman, P (1986). A New Pan-Cultural Facial Expression of Emotion. San Francisco: University of California.

Ernawati (2018). The Uses of Taboo Words to Express Anger in the Bad Teacher Movie. Balikpapan: Universitas Balikpapan.

Fromkin,V. et al. (2003) An introduction to language Wadsworth. United States.

Guillain, C. (2015). Qualitative Data Analysis: An Expanded Sourcebook. London: Sage Publication.Inc.

Holmes, J. (2013) An Introduction to Sociolinguistic, Fourth edition. New York: Routledge.

Hymes, D. (1974) Foundation in Sociolinguistic, An Etnoghraphic Approach. Philadelphia: University of Pennislavia Press.

Jay, T. and Janschewitz, K. (2008) Journal of Politeness Research. Walter de Gruyter Gmbh \& $\mathrm{CO} . \mathrm{KG}$.

Kim, H. \& Ko, D. (2007) Culture and Self-Expression. Santa Barbara: University of California.

Klarer, M. (2004) An Introduction to Literary Studies, second Edition. New York: Routledge.

Kurniawati, R. I. (2018) Euphemism as the way of smoothening taboo language in the novel Fifthy Shades of Darker by E. L. James. Balikpapan: Universitas Balikpapan.

Miles, B. M. and Huberman, M. Analisis Data Kualitatif Buku Sumber tentang Metode Baru.Jakarta: UIP.

Redhead, L, (2004) Peepshow. Australia: Allen \& Unwin,

Sumarsono. (2002), Sosiolinguistik. Yogyakarta: SABDA.

Trudgill, P. (2000) An introduction to language and society. England: Penguin books.

Wardraugh, R. (2006) An Introduction to Sociolinguistic: Fifth Edition, UK: Blackwell Publisher, Ltd. 